\title{
COMPARATIVE ANALYSIS OF GENETIC MAPS OF Bos taurus L. AND Capra hircus L.
}

\author{
L.K. Ernst', P.M. Klenovitskii', V.A. Bagirov', B.S. Iolchiev', N.A. Zinovieva', \\ V.V. Kalashnikov', V.I. Fisinin', M.A. Zhilinskii ${ }^{1}$ \\ ${ }^{I}$ All-Russia Research and Development Institute for Livestock Husbandry, RAAS, Dubrovitsy settlement 142132, Moscow province, Russia \\ e-mail: e-mail:klenpm@mail.ru \\ ${ }^{2}$ Russian Academy of Agricultural Sciences, Moscow 117218, Russia \\ e-mail:vugarbagirov@mail.ru
}

Received January 7, 2013

S u m m a r y

With the use of data base of genetic maps of animals and developed software the authors have made comparative analysis of gene orders in two representatives of Bovidae family, Bos taurus L. and Capra hircus L. It was shown the high similarity of gene orders of homeological chromosomes in compared species, with the exception of 9th and 14th chromosome pairs.

Keywords: divergence, genome, genetic maps, homology, karyotype, chromosome, chromosome maps.

Today, phylogenetic research is supported by achievements of modern biology, such as the knowledge of structure and functioning of chromosome apparatus. Cytogenetic techniques are an important tool in systematics and phylogeny of mammals (1-3). In recent decades, the study of chromosome sets is a part of applied studies $(4,5)$, including the works on conservation and rational use of animal gene pools (6-10). Analysis of the fine structure of chromosomes is widely used in evolutionary genetics. One of approaches in the study of homology of chromosomes and chromosomal regions in various mammalian species is the comparison of differences in their striation.

The analysis of cytogenetic similarities and karyotype evolution are described in number of scientific works (11-13). According to A.S. Grafodatsky and L.S. Bitueva (12), homeologous chromosomal regions can be identified from the nature of striation more often and exactly the less the compared karyotypes are rearranged relative to each other. With a few exceptions, homology is clearly seen in compared species within one genus or related genera. Sometimes it can be more or less reliably identified within a family.

Recent works on assessment of genomic similarity often use molecular genetic markers (14-19). However, the most accurate measure of similarity (identity) of genomes is only the fact that chromosomes or chromosomal regions contain similar nucleotide sequences arranged in the similar order, regardless of their alleles.

The comparison of genetic composition of individual chromosomes in different species was the subject of many studies (2028), as well as phylogenetic analysis based on comparison of gene maps (29-32). The comparison of chromosomal structure revealed divergent pathways in cytogenetic evolution of sheep species (33-37). The study of gene orders of Bos taurus L. and Ovis aries L. allowed a detailed analysis of their karyotypic divergence (32). However, in all these studies the subjects were species with pronounced cytogenetic differences.

In this work the authors compared gene maps of two closely relative species - members of the family Bovidae with similar chromosome sets - Bos taurus L. and Capra hircus L., in order to find differences in organization of their genomes at the level of gene orders.

Technique. The study was conducted using the own databank of chromosomal location of markers in B. taurus L. and $C$. hircus L. that included generalized information from databases NAGRP (National Animal Genome Research Program, USA) (38) and INRA $(39,40)$ with the data about location of 28282 and 708 markers, respectively. Chromosomal location of 249 these markers was known in both species. Along with it, the authors used the data of A. Eggen and R. Fries (41), J.J. Lauvergne et al. (42), J. Maurico et al. (43), and Bovine genome DataBase (44). Analysis of gene maps was performed according to the algorithms described previously $(28,29)$.

Cytogenetic characteristics of the compared species were studied in chromosome preparations of a 72-hour culture of peripheral lymphocytes stimulated with Concanavalin A ("Paneco", Russia) at a dose of $10 \mathrm{ug} / \mathrm{ml}$. Culturing of the lymphocytes, preparation and staining of chromosomes were carried out by conventional methods (45) with own modifications (46).

Results of the study were documented with a digital video camera KC-583C ("Digital", Tawan) and Windows-compatible software. Image processing and karyotyping were conducted following the earlier reported method (46).

Results. Species of the family Bovidae show high cytogenetic variability. It is believed that initial karyotype of bovids was a set of 60 chromosomes with 29 pairs of uni-armed autosomes. The divergence of phylogenetic branches occurred 15-20 million years ago and gave rise to modern representatives of this family. According to comparison of chromosome sets of various bovids, it is accepted that evolution of karyotypes in this family occurred mainly through centric fusions (47). Changes in morphology of sex chromosomes of bovids are assumed as result of pericentric inversions.

The modern genus Capra is considered as karyologically closest to the ancestral bovids by monomorphic structure of chromosomes $(3,45,48,49)$. Karyotype of $C$. hirous is the most well studied in the genus $(50-53)$. Domestic goat has a diploid set of 60 chromosomes, where 29 pairs are acrocentric autosomes. X-chromosome is a large acrocentrics, while Y-chromosome is metacentric and one of the smallest in the set (Figure 1, A). Accurate identification of chromosomes except Y-chromosome is only possible with the use of differential staining. B. taurus is another domestic bovid the most close to C. hirous in number and morphology of chromosomes (Fig. 1, B).

Diploid set of the both species is 60 , and the number of arms in autosomes - 58; the species have identical patterns of homologous chromosomes, except the $9^{\text {th }}$ and $14^{\text {th }}$ pairs $(4,5)$. Most of the chromosomes of $B$. taurus and $C$. hirous show relatively 
uniform alternation of light and dark bands across the length. These species differ in morphological organization of female sex chromosomes: $\mathrm{X}$ chromosome of $B$. taurus is a large metacentric. This fact is associated with pericentric inversion (54)

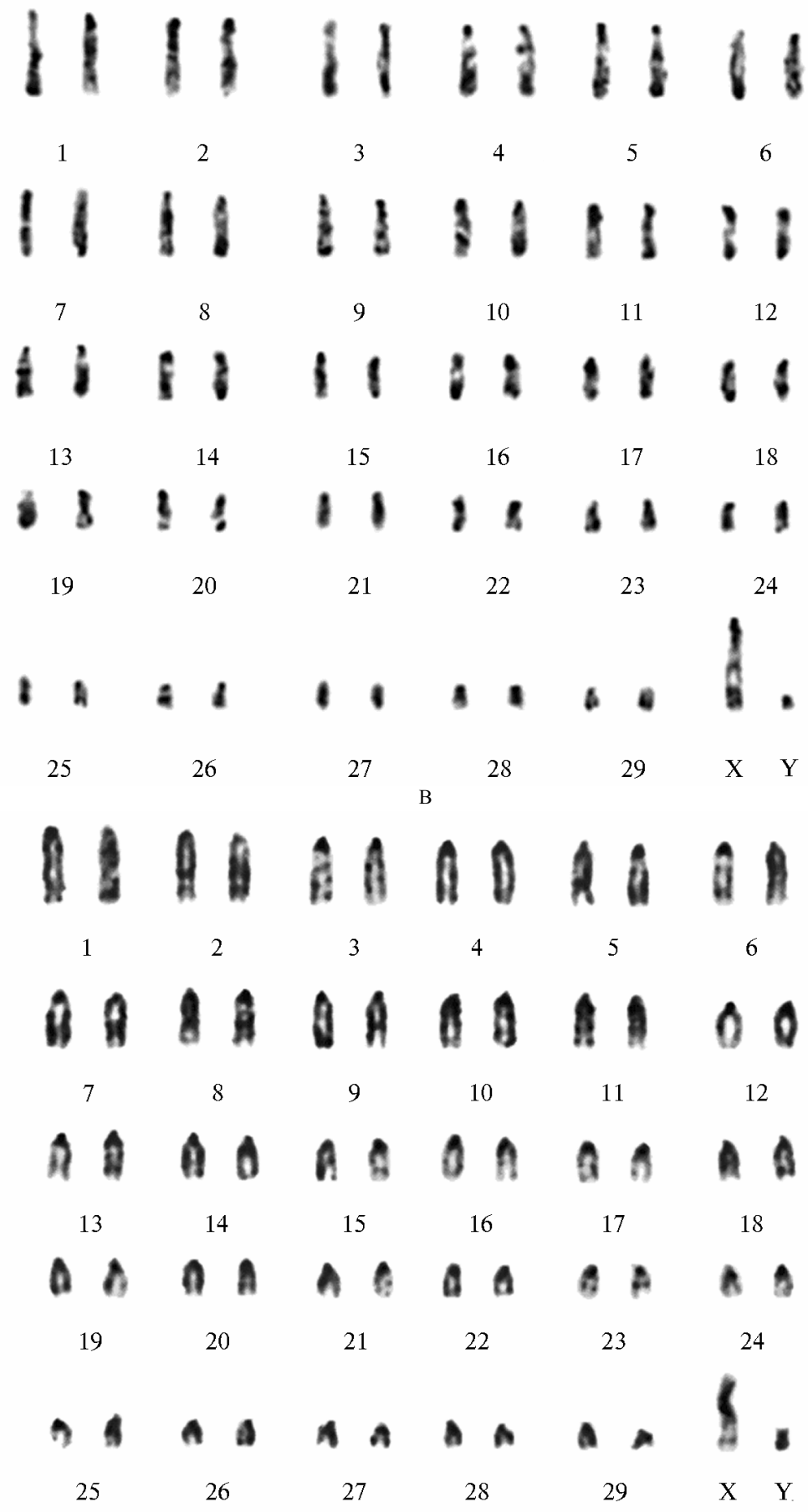

Fig. 1. Karyotypes of Capra hircus L. (male) (A) and Bos taurus L. (male) (B). Giemsa stained, magnification $\times 100$.

В таблице представлены данные о соответствии генного состава хромосом B. taurus и C. hircus., в частности сведения 95 маркеров первого и 154 маркеров второго типа. Для 22 пар хромосом у анализируемых видов отмечалось полное совпадение их генного состава. В эту группу входят хромосомы 2-5-й, 9-13-й, 15-19-й, 21-25-й, 28-й, 29-й пар и половые хромосомы. В качестве примера на рисунке 2, А приведены генные карты 2-й и 5-й пар хромосом крупного рогатого скота и козы.

The table presents the composition of genes in chromosomes of B. taurus and C. hircus in respect to 95 markers of the first type and 154 markers of the second type. In these species, 22 pairs of their chromosomes have identical genetic composition: the pairs $2-5^{\text {th }}, 9-13^{\text {th }}, 15-19^{\text {th }}, 21-25^{\text {th }}, 28^{\text {th }}, 29^{\text {th }}$, and sex chromosomes. For example, Figure 2 , A shows gene maps for the $2^{\text {nd }}$ and $5^{\text {th }}$ pairs of chromosomes in cattle and goat. 
Composition of genes in chromosomes of Capra hircus L. (male) and Bos taurus L. (male)

\begin{tabular}{|c|c|c|}
\hline \multicolumn{2}{|c|}{ C. hircus L. } & \multirow{2}{*}{$\begin{array}{c}\text { B. taurus L. } \\
\text { № pairs of chromosomes and number of genes }\end{array}$} \\
\hline № pair of chromosomes & arm & \\
\hline $1^{\mathrm{st}}$ & $\mathrm{q}$ & $1 \mathrm{q}(23: 9,14) ; 16 \mathrm{q}(1: 0,1)$ \\
\hline $2^{\text {nd }}$ & $q$ & $2 q(14: 6,8)$ \\
\hline $3^{\text {rd }}$ & $q$ & $3 q(10: 2,8)$ \\
\hline $4^{\text {th }}$ & $\mathrm{q}$ & $4 \mathrm{q}(9: 3,6)$ \\
\hline $5^{\text {th }}$ & $q$ & $5 \mathrm{q}(11: 4,7)$ \\
\hline $6^{\text {th }}$ & $\mathrm{q}$ & $6 q(5: 3,2)$ \\
\hline $7^{\text {th }}$ & $q$ & $7 \mathrm{q}(5: 3,2)$ \\
\hline $8^{\text {th }}$ & $\mathrm{q}$ & $8 \mathrm{q}(7: 2,5) ; 11 \mathrm{q}(1: 0,1)$ \\
\hline $9^{\text {th }}$ & $\mathrm{q}$ & $9 q(6: 1,5)$ \\
\hline $10^{\text {th }}$ & $\mathrm{q}$ & $10 \mathrm{q}(10: 4,6)$ \\
\hline $11^{\text {th }}$ & $\mathrm{q}$ & $11 \mathrm{q}(16: 5,11)$ \\
\hline $12^{\text {th }}$ & $q$ & $12 \mathrm{q}(9: 3,6)$ \\
\hline $13^{\text {th }}$ & $\mathrm{q}$ & $13 q(6: 3,3)$ \\
\hline $14^{\text {th }}$ & $q$ & $9 q(3: 0,3) ; 14 q(8: 3,5)$ \\
\hline $15^{\text {th }}$ & $\mathrm{q}$ & $15 \mathrm{q}(7: 3,4)$ \\
\hline $16^{\text {th }}$ & $q$ & $16 \mathrm{q}(9: 1,8)$ \\
\hline $17^{\text {th }}$ & $\mathrm{q}$ & $17 \mathrm{q}(7: 2,5)$ \\
\hline $18^{\text {th }}$ & $\mathrm{q}$ & $18 \mathrm{q}(10: 6,4)$ \\
\hline $19^{\text {th }}$ & $\mathrm{q}$ & $19 q(4: 1,3)$ \\
\hline $20^{\text {th }}$ & $\mathrm{q}$ & $1 \mathrm{q}(1: 1,0) ; 9 \mathrm{q}(1: 0,1) ; 20(6: 0,6)$ \\
\hline $21^{\text {st }}$ & $q$ & $21 \mathrm{q}(6: 2,4)$ \\
\hline $22^{\text {nd }}$ & $q$ & $7 \mathrm{q}(1: 0,1) ; 22 \mathrm{q}(7: 3,4)$ \\
\hline $23^{\text {rd }}$ & $q$ & $23 \mathrm{q}(5: 2,3)$ \\
\hline $24^{\text {th }}$ & $\mathrm{q}$ & $24 q(6: 0,6)$ \\
\hline $25^{\text {th }}$ & $q$ & $25 \mathrm{q}(8: 2,6)$ \\
\hline $26^{\text {th }}$ & $q$ & $14 \mathrm{q}(1: 0,1) ; 26 \mathrm{q}(4: 1,3)$ \\
\hline $27^{\text {th }}$ & $q$ & $17 \mathrm{q}(1: 1,0) ; 26 \mathrm{q}(1: 0,1) ; 27 \mathrm{q}(4: 0,4)$ \\
\hline $28^{\text {th }}$ & q & $28 \mathrm{~g}(5: 0,5)$ \\
\hline $29^{\text {th }}$ & $\mathrm{q}$ & $29 \mathrm{q}(4: 0,4)$ \\
\hline $\mathrm{X}$ & & $X(5: 3,2)$ \\
\hline $\mathrm{Y}$ & & $\mathrm{Y}(1: 1,0)$ \\
\hline
\end{tabular}

It should be noted that for a part of genetic markers reviewed in this work and common for cattle and goat there's yet no data on exact location on chromosomes.

7 chromosomal pairs of $C$. hircus and B. taurus showed a partial mismatch of gene composition. The most significant differences in order of genes were found in the $14^{\text {th }}$ pair (Fig., B).
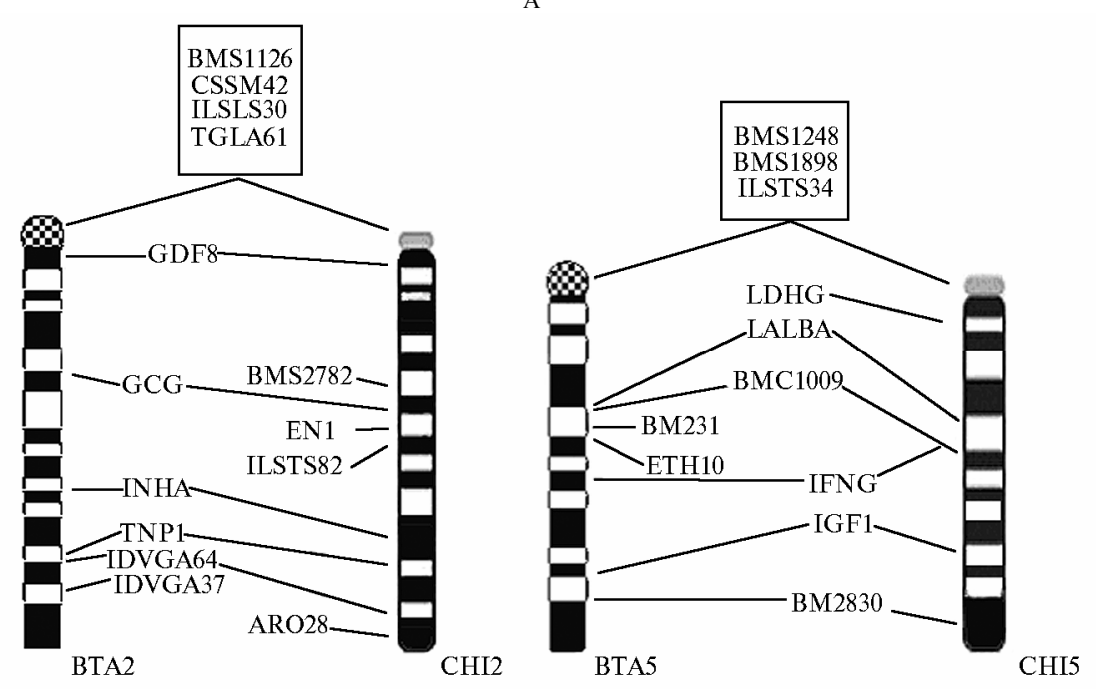


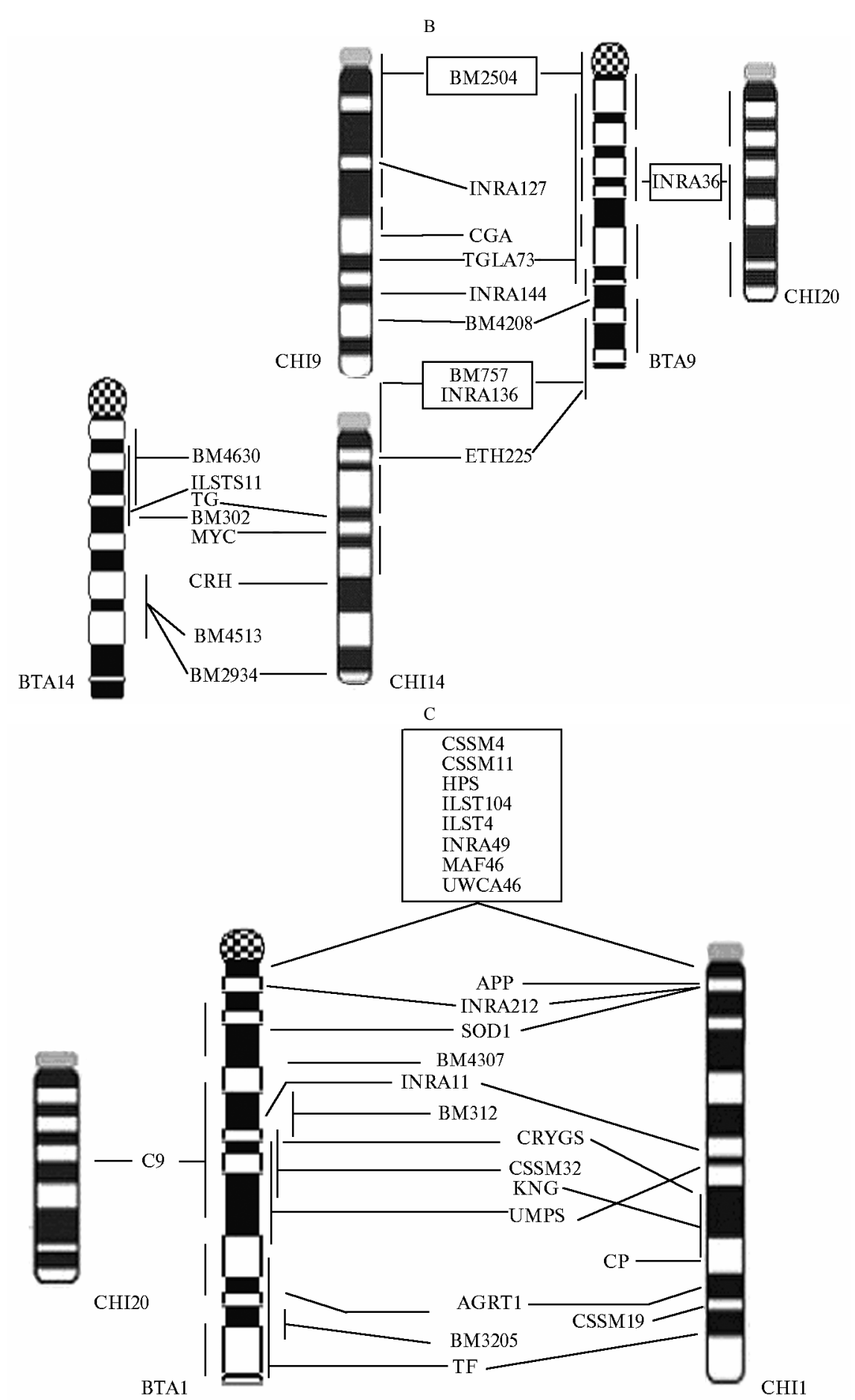

Fig. 2. Comparison of gene maps for the $2^{\text {nd }}$ and $5^{\text {th }}$ pairs of chromosomes of Capra hircus L. (CHI2, CHI5) and Bos taurus L. (BTA2, BTA5) (A); $9^{\text {th }}$ and $14^{\text {th }}$ pairs of $C$. hircus (CHI9, CHI14) and B. taurus (BTA9, BTA14) (B); $1^{\text {st }}$ pair of $C$. hircus (CHI1) and B. taurus (BTA1) (C). In square - symbols of genes with indefinite location. Gene $C 9$ and marker INRA36 are located on the $20^{\text {th }}$ chromosome of goat.

On the $14^{\text {th }}$ chromosome of $C$. hircus there were located 11 genetic markers peculiar to cattle chromosomes BTA14 (8 markers) and BTA9 ( 3 markers). On the $9^{\text {th }}$ chromosome of $B$. taurus there were located 10 genetic markers whose localization is known in goat on CHI9 (9 markers), HI14 (3 markers), and CHI20 (1 marker). Unfortunately, exact localization of genetic markers on BTA9 is indefinite, which doesn't allow revealing the nature of changes in genetic composition of these chromosomes. Another obstacle is the absence of data about reaper genes of BTA14 localized outside CHI14.

Goat chromosome of the $1^{\text {st }}$ pair was similar to BTA1 in composition of genes. But along with markers located on CHI1, BTA1 contained the gene for the $9^{\text {th }}$ component of complement $(C 9)$ that in goat is located on the $20^{\text {th }}$ pair (Fig. 2, B).

In cattle, the $8^{\text {th }}$ and $22^{\text {nd }}$ pairs of chromosomes corresponded to CHI8 and CHI22 for the most of markers. But on CHI8 there was also found DNA-marker HEL13 known in cattle chromosome BTA11, and on CHI22 - a microsatellite marker BM7160 peculiar to BTA7.

Comparison of the $26^{\text {th }}$ chromosomal pair of these species revealed 4 similar markers on CHI26 and BTA26. In addition, on BTA26 there was the marker CSSM43 associated with CHI27, and on CHI26 - the marker BM4305 also found on BTA14.

On the $20^{\text {th }}$ pair of goat chromosomes it was found 8 markers, 6 of which were present on BTA20, and the markers $C 9$ and INRA36 located on, respectively, BTA1 and BTA9. The $27^{\text {th }}$ pair of goat chromosomes contained 6 markers, 4 of which were associated with BTA27 in B. taurus, as well as the gene for coagulation factor 11-F11 and microsatellite CSSM43 - with chromosomes of the $17^{\text {th }}$ and $26^{\text {th }}$ pairs, respectively.

Thus, the compared bovid species showed high similarity of genetic composition. However, evolutionary divergence of their 
karyotypes was associated with exchange of genetic material between non-homologous chromosomes. All peculiarities of this process not revealed by classical cytogenetic analysis necessitate the analysis of genomes at the level of gene maps even in closely related species.

\section{REFERENCES}

1. Dzuev R.I. Khromosomnye nabory mlekopitayushchikh Kavkaza [Chromosome Sets of Caucasian Mammals]. Nal'chik, 1998.

2. Klenovitskii P.M., Bagirov V.A., Iolchiev B.S., Dotsev A.V. Dostizheniya nauki i tekhniki APK, 2003, 10 : 17-19.

3. Orlov V.N., Bulatova N.Sh. Sravnitel'naya tsitogenetika i kariosistematika mlekopitayushchikh [Comparative Cytogenetics and Karyosystematics of Mammals]. Moskva, 1983.

4. Popescu P. Cytogenetique des mammiferes d'elevage. Paris, INRA, 1989.

5. Yakovlev A.F. Tstogeneticheskaya otsenka plemennykh zhivotnykh [Cytogenetic Evaluation of Breeding Animals]. Moskva, 1985.

6. Bagirov B.A., Klenovitskii P.M., Nasibov Sh.N., Iolchiev B.S., Zinov'eva N.A., Ernst L.K. Dostizheniya nauki i tekhniki APK, $2009,8: 41-43$.

7. Bagirov V.A., Gladyr' E.A., Ernst L.K., Klenovitskii P.M., Zinov'eva N.A., Nasibov Sh.N. Sel'skokhozyaistvennaya Biologiya [Agricultural Biology], 2009, 2: 37 42.

8. Bagirov V.A., Klenovitskii P.M., Nasibov Sh.N., Iolchiev B.S., Zinov'eva N.A., Ernst L.K., Gusev I.V., Kononov V.P. Sel'skokhozyaistvennaya Biologiya [Agricultural Biology], 2009, 6: 27-33.

9. Nasibov Sh.N., Bagirov V.A., Klenovitskii P.M., Iolchiev B.S., Zinov'eva N.A., Voevodin V.A., Amirshoev F S. Dostizheniya nauki i tekhniki APK, 2010 , 8: 59-62.

10. Nasibov Sh.N., Iolchiev B.S., Klenovitskii P.M., Bagirov V.A., Voevodin V.A., Zinov'eva N.A. Dostizheniya nauki i tekhniki APK, $2010,9: 50-51$.

11. Anis'kin V.M., Isaev S.I., Shchipanov N.A. Genetika, 1996, 32(1): 83-93.

12. Grafodatskii A.S., Bitueva L.S. Gomologiya G-okrashennykh khromosom mleko-pitayushchikh. Genetika, 1987, 23(1): 95-104.

13. Iolchiev B.S., Klenovitskii P.M., Strekozov N.I., Abilov A.I., Bagirov V.A., Sipko T.P. Dostizheniya nauki i tekhniki APK, $2006,2: 27-29$.

14. Gladyr' E.A., Gorelov P.V., Maurcheva V.N., Shakhin A.V., Chinarov Yu.I., Zinov'eva N.A. Dostizheniya nauki i tekhniki APK, 2011 , 8: 51-54.

15. Gladyr' E.A., Selionova M.I., Zinov'eva N.A. Ovtsy, kozy, sherstyanoe delo, 2007, 4: 19-24.

16. Gladyr' E.A., Shadrina Ya.L., Gorelov P.V., Davaakhuu L., Popov R.G., Matyukov V.S., Agyshova A.K., Zinov'eva N.A. Sel'skokhozyaistvennaya Biologiya [Agricultural Biology], 2011, 6: 65-69.

17. Gladyr' E.A., Ernst L.K., Kostyunina O.V. Sel'skokhozyaistvennaya Biologiya [Agricultural Biology], 2009, 2: 16-26.

18. Gorelov P.V., Kol'tsov D.N., Zinov'eva N.A., Gladyr' E.A. Sel'skokhozyaistvennaya Biologiya [Agricultural Biology], 2011,6 : $37-40$.

19. Gladyr' E.A., Zinov'eva N.A., Bagirov V.A., Amirshoev F.S., Volkova V.V., Klenovitskii P.M., Karpov A.P., Ernst L.K. Dostizheniya nauki i tekhniki APK, 2012, 8: $58-62$.

20. Ashwell M.S., Rexroad C.E., Miller Jr.R.H. et al. Mapping economic trait loci for somatic cell score in Holstein cattle using microsatellite markers and selective genotyping. Anim. Genet., 1996, 27: 235-242.

21. Board T.E., Lambeth M., Burkin D.J. et al. Physical mapping confirms that sheep chromosome 10 extensive conserved synteny with cattle chromosome 12 and human chromosome 13. Anim. Genet., 1996, 27: 249-253.

22. Casas E., Barendse W., Beever J.E. et al. Bovine chromosome 4 workshop: consensus and comprehensive linkage maps. Anim. Genet., 1999 , $30: 375-377$.

23. Cockett N.E., Shay T.L., Smit M. Analysis of the sheep genome. Physical Genomics, 2001, 7: 69-78.

24. Rexoad C.E. III, Yang Y., Womak J.E. Use of the human transcript map to assing five loci to bovine chromosome. Anim. Genet., $1999,30: 384-385$.

25. Sonstegard T.S., Kappes S.M., Keele J.W. et al. Refinement of bovine chromosome 2 linkage map near the mh locus reveals rearrangements between the bovine and humans genes. Anim. Genet., 1998, 29: 341-347.

26. Sun H.S., Yerle M., Pinton P. et al. Physical assignment of human chromosome 13 genes on pig chromosome 11 demonstrate extensive synteny and gene order conservation between pig and human. Anim. Genet., 1999, 30: 304-308.

27. Taylor J.F., Eggen A., Aleyasin A. et al. Report of first workshop on the genetic map of bovine chromosome 1. Anim. Genet., 1998, 29: 228-235.

28. Klenovitskii P.M., Marzanov N.S., Marzanov YU.S., Bagirov V.A., Abdul Akhad Bisvas A.K.M. Vestnik Rossiiskoi akademii sel'skokhozyaistvennykh nauk, 2004, 3: $72-75$

29. Bagirov V.A., Klenovitskii P.M., Iolchiev B.S., Zinov'eva N.A. Dostizheniya nauki i tekhniki APK, 2012, 8: $42-44$.

30. Zakharov I.A., Nikiforov V.S., Stepanyuk E.V. Genetika, 1996, 32(1): 128-132.

31. Zakharov I.A. Geneticheskie karty sel'skokhozyaistvennykh zhivotnykh: Informatsion-no-spravochnye materialy [Gene Maps of Agricultural Animals: Reference Information]. Moskva, 1993.

32. Abdul Akhad Bisvas A.K.M. Sravnitel'nyi analiz genomov krupnogo rogatogo skota i ovets. Kandidatskaya dissertatsiya [Comparative Genomic Analysis of Cattle and Sheep, Candidate Sci. Dissertation]. Sankt-Peterburg, 2004.

33. Bunch T.D. Fundamental karyotype in domestic and wild species of sheep Identity and ranking of autosomal acrocentrics involved in biarmed formations. $J$. Heredity, 1978, 69(2): 77-80.

34. Bunch T.D., Nadler C.F., Simmons L. G-band patterns, hemoglobin, and transferrin types of the bharal chromosomal evolutionary relationships with sheep and goats. J. Hered., 1978, 69(5): 316-320.

35. Bunch T.D., Vorontsov N.N., Lyapunova E.A., Hoffmann R.S. Chromosome number of Severtzov's sheep (Ovis ammon severtzovi): G-banded karyotype comparisons within ovis. J. Hered., 1998, 89(3): 266-269.

36. Bunch T.D., Wu C., Zhang Y.-P., Wang S. Phylogenetic analysis of snow sheep (Ovis nivicola) and closely related taxa. J. Hered., 2006, 97(1): 21-30.

37. Bagirov V.A., Klenovitskii P.M., Iolchiev B.S., Zinov'eva N.A., Kalashnikov V.V., Shilo O.V., Soloshenko V.A., Nasibov Sh.N., Kononov V.P., Kolesnikov A.V. Sel'skokhozyaistvennaya Biologiya [Agricultural Biology], 2012, 6: 43-48.

38. National Animal Genome Research Program NRSP-8 Bioinformatics Coordination Program. http://www.animalgenome.org/

39. Institut National de Recherche Agronomique. Welcome to Bovmap Database. http://dga.jo-uy.inra.fr/cgi-bin/lgbc/main.pl?BASE=

40. Institut National de Recherche Agronomique. Welcome to Goatmap Database. http://dga.jo-uy.inra.fr/cgi-bin/lgbc/main.pl?BASE=goat

41. Eggen A., Fries R. An integrated cytogenetic and meiotic map of bovine genome. France-Schweiz, 1994.

42. Lauvergne J.J., Dolling C.H.S., Renieri C. Mendelian inheritance in sheep (MIS 96). Clamart-Camerino, 1996.

43. De Gostari M.J., Brad A., Bred A. et al. A second-generation linkage map of sheep genome. Mammalian Genome, 1998, 9: 204-209.

44. The Bovine genome DataBase. http://www.bovinegenome.org/drupal/ bovine/

45. Grafodatskii A.S., Radzhabli S.I. Khromosomy sel'skokhozyaistvennykh i laboratornykh mlekopitayushchikh. Atlas [Chromosomes of Agricultural and Laboratory Mammals. An Atlas]. Novosibirsk, 1983.

46. Klenovitskii P.M., Bagirov V.A., Zinov'eva N.A., Nasibov Sh.N., Iolchiev B.S. Tsitogenetika zhivotnykh. Moskva, 2007.

47. Wurster D.H., Benirschke K. Chromosome studies in the superfamily Bovoidae. Chromosoma, 1968, 25: 152-171.

48. Diploid numbers mammalian. http://www.bionet.nsc.ru/labs/chromosomes/mammalia.htm

49. Di Berardino D., Hayes H., Fries R., Long S.E. ISCNDA (International System for Cytogenetic Nomenclature of Domestic Animals). Cytogenet. Cell. Genet., 1990, 53(1): 65-79.

50. Evans H.J., Buckland R.A., Sumner A.T. Chromosome homology and heterochromatin in goat, sheep and ox studied by banding techniques. Chromosoma, 1973 , 42(4): 383-402.

51. Iannuzzi L., Meo G.P., Perucatti A. An improved characterization of goat chromosomes by means of G- and R-band comparison. Hereditas, 1994, 120(3): 245-251.

52. Iannuzi L., Di Meo G.P., Perucatti A. G- and R-banded prometaphase karyotypes in goat (Capra hircus L.). Caryologia, 1996, 49(2): 267-277.

53. Hayes H., Petit E. Comparison of RBG-banded karyotypes of cattle, sheep and goat. Citogenet. Cell Genet., 1991, 57(1): 51-55.

54. Buckland R.A., Evans H.J. Cytogenetic aspects of phylogeny in the Bovidae. I. G-banding. Cytogenet. Cell. Genet., 1978, 21(1): 42-63. 